\title{
Morphology Research of Windmill Palm (Trachycarpus fortunei) Material
}

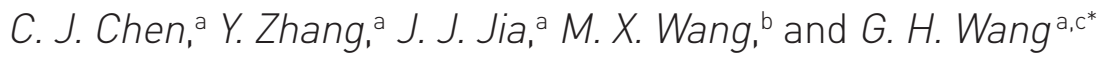 \\ ${ }^{a}$ College of Textile and Clothing Engineering, Soochow University, 215006 Suzhou, P.R. China \\ ${ }^{b}$ Violet Home Textile Company, 226311 Nantong, P.R. China \\ c Nantong Textile \& Silk Industrial Technology Research Institute, 226108 Nantong, P.R. China
}

\begin{abstract}
\| Abstract
Windmill palm (Trachycarpus fortunei) fibre was obtained from different parts of windmill-palm trunk sheath and then treated by sodium hydroxide solution and hydrogen peroxide to obtain the treated palm fibril. The appearance of raw windmill palm fibre and treated palm fibril, morphological characteristics, and statistical analysis of fibril length, diameter, and degree of hollowness were studied. The results indicate that the cylindrical windmill palm fibre has a sharp end. Silica-bodies attach themselves uniformly over the fibre, forming a rough surface. Spindly treated palm fibril without convolution has an ellipse cross-section and a larger lumen. Where we obtain the palm fibre has little effect on the characteristics of the fibril. The average length of treated palm fibril is $643.60 \mu \mathrm{m}$ and the average long diameter is $10.35 \mu \mathrm{m}$. The degree of hollowness by elliptic model and paper-cut method correspond well and the difference between them is only $0.36 \%$. Windmill palm fibril is a natural hollow fibre with a degree of hollowness of about $47.21 \%$.
\end{abstract}

\author{
$\|$ Keywords \\ Windmill palm, fibre, fibril, morphology structure
}

\section{Introduction}

In the current decade, natural fibres such as banana fibre, sugarcane fibre, ${ }^{1}$ bamboo fibre, ${ }^{2}$ kenaf fibre, ${ }^{3}$ sisal fibre, ${ }^{4}$ and palm fibre ${ }^{5}$ attract broad attention. Natural fibres have major advantages over some synthetic fibres, such as glass fibre, that makes them very competitive. Such unique characteristics include low cost, availability, energy recovery, reduced dermal and respiratory irritation, and biodegradability. ${ }^{6}$ According to our literature search, the articles on palm fibre are mainly about date palm fibre and oil palm fibre. The composition, mechanical property, thermal property, and annual world production of date palm fibres, ${ }^{7,8}$ as well as oil palm fibres, ${ }^{9,10}$ have been studied. Most of these studies are aimed at using the abundant natural fibres in bio-composites, ${ }^{11,12}$ to improve the mechanical properties.

Windmill palm is a well-adapted evergreen tree covered with palm trunk sheath. The tree has a good property of wind resistance, strong adaptation to the environment, and great power in reproduction. Therefore, it is widely distributed in Chang Jiang area, especially in Sichuan, Yunnan, Guizhou, and Hubei province. ${ }^{13}$ Windmill palm is one of the most abundant resources in China. The yield of windmill palm in Hong He country Yunnan City alone, reached 4000 tons in $2012,{ }^{14}$ and made palm resources cheaper and more available. After annual trimming operations, enormous quantities of palm fibre wastes are discarded

*Corresponding author: Prof. Guo-He Wang

e-mail: wangguohe@suda.edu.cn directly. Very few attempts have been made for their utilization, probably due to the lack of sufficient structure and property data. Systematic studies for knowing their properties and morphology may bridge this gap while leading to value addition to these natural materials. ${ }^{1}$ The further development and use of windmill palm materials is not only beneficial to protect the environment and broaden the range of forest products, but can also make up for the inadequacy of natural fibre resources.

The chemical composition of untreated palm vascular bundles or so-called palm fibres in trunk sheaths of the windmill palm was estimated to be $w$ (cellulose) $=28.2 \%$, $w($ hemicellulose $)=20.6 \%, w($ lignin $)=44.07 \%$, and $w($ wax $)=3.8 \% .{ }^{15}$ The large amount of lignin and hemicellulose not only makes the fibre brittle and hard, but also, putting these palm vascular bundles together, contributes to the oversized diameter of the palm fibres. It absolutely limits the use of this material. Today, in China, it can only be used to make brooms, coir ropes, brushes, and mattresses. ${ }^{15}$ Similar as with other lignocellulosic materials, high lignin and hemicelluloses percentage of windmill palm fibre also cannot be ignored. Alkali treatment can dissolve hemicelluloses, lignin, and silica. In this way, the treated windmill palm fibril can be obtained. It helps to know the structure of windmill palm materials more clearly.

Morphology of windmill palm material is one of the most important factors that affects fibre quality. Though various studies have been carried out on different parts of fibre from date palm and oil palm, there is no literature on windmill palm fibres and treated fibrils. This study was conduct- 
ed in order to investigate the nature, surface features, and structure of the windmill palm materials. The portrait and cross-section of windmill palm fibres and treated fibrils, the length, diameter and degree of hollowness were also analysed in order to study the morphological characteristics and reveal the characteristics of palm material to make it easier to utilize them for more valuable products.

\section{Materials and equipment}

\subsection{Materials}

\subsubsection{Preparation of windmill palm fibre}

The trunk sheaths used in this study were obtained from a windmill palm in Mount Huang Anhui province, China. Palm fibre can be run out from different parts of the palm trunk sheaths. By rotating around the trunk counter-clockwise about $45^{\circ}$, the palm fibre is of huge diameter, which can be numbered \#1. The palm fibre in the direction of about $45^{\circ}$ clockwise to the trunk, and the fine fibre bends in the middle of the palm trunk sheaths were numbered $\# 2$, \#3, respectively. Fibre was washed under running water several times, and dried naturally.

\subsubsection{Preparation of windmill palm fibril}

The palm fibres \#1, \#2, \#3 were treated by aqueous hydrogen peroxide solution, $w\left(\mathrm{H}_{2} \mathrm{O}_{2}\right)=4 \%$, and aqueous sodium hydroxide solution, $w(\mathrm{NaOH})=1.5 \%$, with a 1 : 50 fibre to extractant mass ratio. In order to react completely, the solution needed a stir every 30 minutes at $85{ }^{\circ} \mathrm{C}$ for $4 \mathrm{~h}$. The residue was filtered off by two layers of gauze and then put into the centrifugal tube. The separate fibril was obtained by adding deionized water into the centrifugal tube and by oscillating. Then it was washed with running water to remove any traces of alkali on the surface, dried naturally, and sequentially numbered \#1, \#2, \#3.

\subsection{Test instruments and methods}

\subsubsection{Surface morphology of windmill palm fibril}

The surfaces of raw fibres and treated palm fibrils were observed using scanning electron microscopy, SEM (S-4800, HITACHI, Japan). Windmill palm fibre and fibril were cut by a blade in the natural state to study the cross-section. Raw palm fibre and treated fibril were selected without damage to the surface to study the longitudinal morphology. Before the test, all the samples were coated with a thin-layer of gold with a plasma sputtering apparatus. The observation was performed in high vacuum mode and accelerating voltage between $1.5 \mathrm{kV}$ and $3 \mathrm{kV}$.

\subsubsection{Morphological parameters of windmill palm materials}

Hand measuring method and micrometre were used to test the length and diameter of palm fibre, respectively, by taking an average value of 1000 fibres for each sample. Longitudinal optical micrographs of the treated palm fibril samples with a magnification of 200 were photographed with the Ultra Depth Microscope (VHX-100, KEYENCE, Japan). The micrographs were compared and analysed to tap out the morphological features, such as the length and aspect ratio, by taking an average value of $1000 \mathrm{fi}-$ brils for each sample. Image-proplus 6.0 software was used to analyse these features. The date of different parts of the fibril length was summarized and then Origin 8.0 software was used to analyse the length distribution. The SEM cross-sectional photographs of fibril were studied by Image-proplus 6.0 software to collect the data on thickness of palm fibril cell wall, the long and short diameter, and so on. The raw fibre and treated palm fibrils were observed by SEM and Ultra Depth Microscope, in order to find out nature of the fibrils and surface features. The hollowness of the fibrils was measured by paper-cut method. ${ }^{16}$

\section{Results and analysis}

\subsection{Morphology analysis of windmill palm fibre material}

\subsubsection{Morphological investigation of windmill palm fibre}

The morphology of windmill palm fibre is shown in Fig. 1. The longitudinal view of raw palm fibre shows it is without convolutions. The raw palm fibre is a cylindrical fibre with a sharp end, and an obviously concave-convex surface. Silica-bodies are found in great amount in windmill palm. They attach themselves to circular craters, which are spread relatively uniformly over the fibre surface. The shape, size, and distribution pattern of silica-bodies observed on windmill palm raw fibre are similar to those in the oil palm empty-fruit-fibre as reported by Kwei-Naw Law. The major element of silica is silicon and oxygen. ${ }^{17}$ Silica accumulated in the surface of palm fibre has properties, such as mechanical support, anti-corrosion, and anti-pathogens infringement. ${ }^{15}$ In cross-section view, large cavities in the middle of a vascular bundle can be observed and there are several large vessel elements. The function of these vessel elements is to transport the nutrients. Around the vessel elements there are lots of single palm fibril. The cross-section of each single fibril with a large lumen in the centre has unique shape.
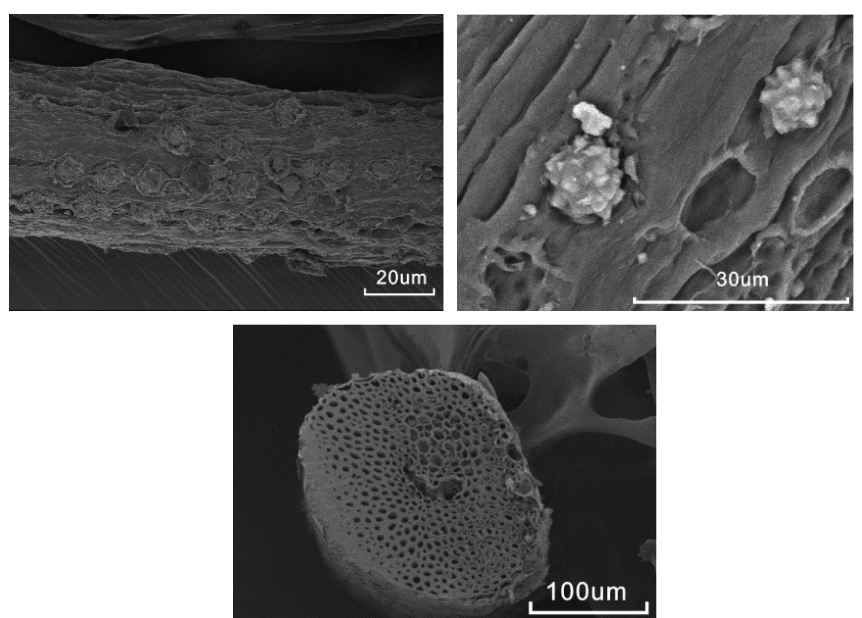

Fig. 1 - Morphology of windmill palm fibre: (left) morphology of lengthwise; (middle) Silica-bodies; (right) cross-section

Slika 1 - Morfologija niti palme vjetrenjače: (lijevo) morfologija po duljini; (u sredini) tijela $\mathrm{SiO}_{2}$; (desno) poprečni presjek 


\subsubsection{Morphological investigation of treated palm fibril}

Ning $\mathrm{Li}$ found that the royal palm sheath fibres were covered by layers of lignin together with hemicelluloses..$^{18}$ The structure of royal palm sheath fibres is similar to those in windmill palm. Thus, lignin and/or hemicelluloses possibly form physical barriers and/or may cause non-productive binding inhibition to cellulose, which consequently make it difficult to dissolve. Alkali treatment of lignocelluloses, such as windmill palm, dissolve hemicelluloses, lignin, and silica, by hydrolysing uronic and acetic esters, providing single palm fibril. Morphological investigation of palm fibril is shown in Fig. 2. The longitudinal view of windmill palm fibril is like cotton, it is a single cell fibril, but the surface is not smooth. There are fine convex marks around it. The middle of fibril is thick and the diameter in about $70 \%$ of the total length change slightly. The terminal of fibril is tapering and sealing, and the cross-section is round or oval with one irregularly round lumen. The thickness of the palm cell wall is almost uniform.
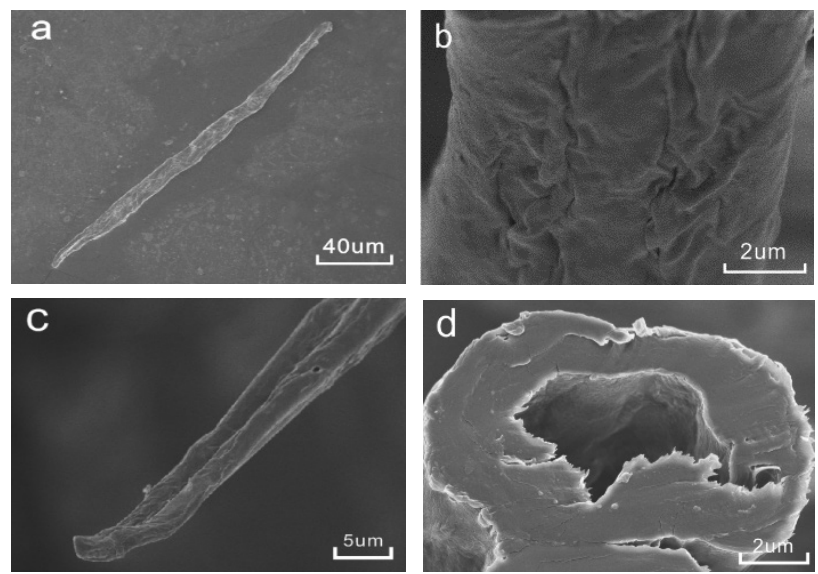

Fig. 2 - Morphology of windmill palm fibril: (a) longitudinal morphology; (b) local amplification of morphology; (c) the end of palm fibril; (d) cross-section

Slika 2 - Morfologija niti palme vjetrenjače: (a) longitudinalna morfologija; (b) lokalno uvećanje morfologije; (c) završetak palmine niti; (d) poprečni presjek

\subsection{Morphometric parameter of windmill palm materials}

\subsubsection{Length, diameter and aspect ratio of windmill palm fibre}

In both the upper and lower surfaces of the palm trunk, sheaths are thick and strait brown fibres interleaved webs, not interwoven with each other. The inner finer filament winding interspersed interwoven together to form a multilayer web. According to the parts where the fibre is grown in the trunk sheaths, the fibre can be divided into three categories: \#1 counter-clockwise about $45^{\circ}$ around the trunk, \#2 about $45^{\circ}$ clockwise to the trunk and \#3 the fine fibre bends in the middle of the palm trunk sheaths. Morphological parameters include length, diameter and aspect ratio of raw palm fibre, which are studied from the different parts in the windmill palm sheath. The length of sample \#1 is in the range from 216 to $678 \mathrm{~mm}$, and the average length is about $371 \mathrm{~mm}$. Whereas, the length of samples \#2 and \#3 are in the range from 121 to $545 \mathrm{~mm}$ and from 52 to $370 \mathrm{~mm}$. The average length of two samples is $341 \mathrm{~mm}$ and $147 \mathrm{~mm}$, while the average diameter of three different raw windmill palm samples is $397 \mu \mathrm{m}$, $218 \mu \mathrm{m}$, and $143 \mu \mathrm{m}$, in the order of \#1, \#2, and \#3. Aspect ratio is calculated by using the length divided by its diameter. The aspect ratio of samples \#1, \#2, and \#3 is 968,1602 , and 1064. From the macroscopic point of view, the length and diameter are largely different with respect to the different parts. For example, the average length and average diameter of \#1 is 2.52 times and 2.78 times of $\# 3$, respectively.

\subsubsection{Morphological analysis of palm fibril in different parts}

Windmill palm fibre in different parts was treated by the alkali-oxygen process to obtain three types of palm fibril. The morphological parameters are shown as follows. The length of different samples of $\# 1^{\prime}, \# 2^{\prime}$, and $\# 3^{\prime}$ is $630.26 \mu \mathrm{m}, 642.00 \mu \mathrm{m}$, and $650.16 \mu \mathrm{m}$, respectively. The cross-section of windmill palm fibril is typically oval, thus the long diameter and short diameter are observed in order to describe the real diameter of windmill palm fibril. The long diameter of \#1' is $10.66 \mu \mathrm{m}, \# 2^{\prime}$ is $10.38 \mu \mathrm{m}$, and $\# 3^{\prime}$ is $9.88 \mu \mathrm{m}$, while the short diameter of $\# 1^{\prime}$ is $7.60 \mu \mathrm{m}, \# 2^{\prime}$ is $7.26 \mu \mathrm{m}$, and \#3' is $6.98 \mu \mathrm{m}$. The thickness of the fibril cell wall is observed; for $\# 1^{\prime}$ is $1.40 \mu \mathrm{m}$, $\# 2^{\prime}$ is $1.32 \mu \mathrm{m}$, and \# $3^{\prime}$ is $1.22 \mu \mathrm{m}$. There are significant differences in the macroscopic size between the different parts of the palm fibre, while the differences between these fibrils are much smaller. The smaller the diameter of fibre is, the longer and thinner the palm fibril will be. However, the maximum difference in the average length, long diameter and short diameter of three palm fibrils are $3.06 \%$, $7.31 \%$, and $8.16 \%$, respectively. Therefore, where we obtain the palm fibre has little effect on the characteristics of palm fibril.

\subsubsection{Morphological analysis of palm fibril}

\subsubsection{Length of palm fibril}

The average length of fibrils is not the only factor in analysing the palm fibril length. The heterogeneity of the length distribution should be taken into consideration as well. Frequency distribution diagram is commonly used..$^{19}$ The length data of three types palm fibril was collected to analyse the distribution. Origin 8.0 software was used to analyse these data and the palm fitting results are shown in Fig. 3. Palm fibril length distribution is a normal distribution, the curve fitting equation $y=0.375+\frac{9400}{326.1} \sqrt{\frac{2}{\pi}} \cdot e^{-\frac{(x-660.1)^{2}}{2 \cdot 326^{2}}}$. 


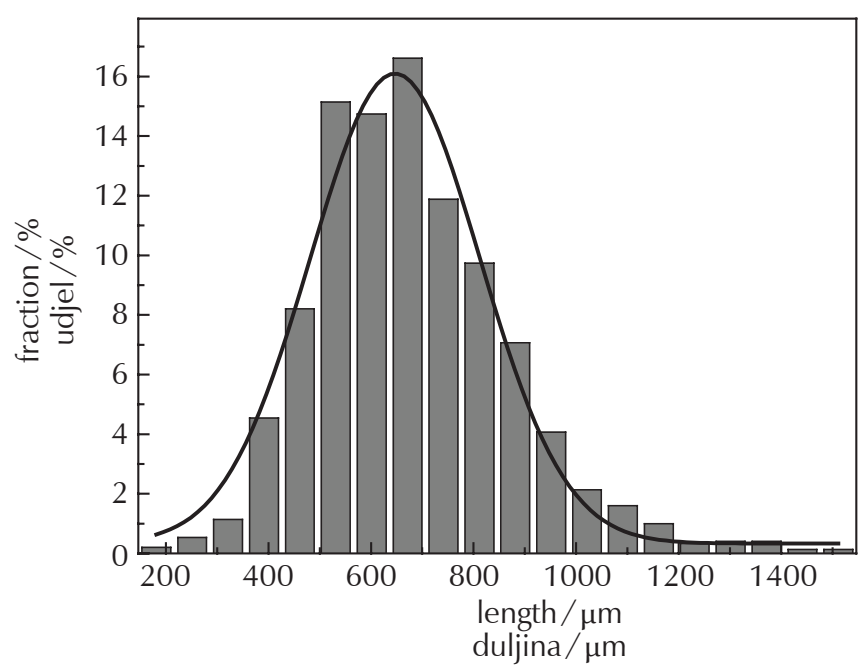

Fig. 3 - Distribution of palm fibril length

Slika 3 - Raspodjela duljine niti palme

Palm fibril length between 500 and $900 \mu \mathrm{m}$ is more than $90 \%$, and the average length is $643.60 \mu \mathrm{m}$. Though the use of such short fibril is not easy, it is still suitable for non-woven materials and pulp.

\subsubsection{Diameter of palm fibril}

The longitudinal view of windmill palm fibril resembles cotton. It is a single cell fibril. The long and short diameters vary widely, so they should be measured separately. The morphology parameters of palm fibre is shown in Table 1 . The average long and short diameters were $10.35 \mu \mathrm{m}$ and $7.33 \mu \mathrm{m}$, respectively. The diameter of cotton is about 13-15 $\mu \mathrm{m}$, of cashmere about 14-16 $\mu \mathrm{m}$, of ramie about $30-40 \mu \mathrm{m},{ }^{20}$ of silk about 11.11-12.93 $\mu \mathrm{m} .{ }^{21}$ Among natural fibre, palm fibril is the finest. Palm fibril has a thin cell wall and a large lumen, aspect ratio is 0.37 to 0.63 . The fibril are thin-walled fibre cells, ${ }^{22}$ that can be used as raw material for papermaking. Palm fibril has a better flexibility and resistance and ability to combine with each other.
All these properties are tuned to a high bonding strength during production of paper by palm fibril. ${ }^{23}$ The thinner the wall is, the easier it is to bond to each other, and the intensity is larger. ${ }^{24}$

\subsubsection{Hollowness of palm fibril}

The cross-sectional photograph of palm fibril was taken by scanning electron microscopy (SEM). The paper was cut along the edge of the lumen and the fibril respectively, and then weighed to calculate the hollowness. ${ }^{2}$ The degree of hollowness of windmill palm fibrils ranges from $25.26 \%$ to $67.31 \%$ and the average degree of hollowness is $47.04 \%$. More than $90 \%$ of palm fibril has a hollowness degree between $35 \%$ and $65 \%$. The largest number of palm fibrils had the hollowness degree between $40-45 \%$ and $50-55 \%$ and they accounted for $17.1 \%$ and $17.3 \%$.

Paper-cut method can reflect the true degree of hollowness, but the procedure is more complicated, labour-intensive and less efficient. ${ }^{25}$ Considering the cross-section as elliptic, an elliptic model can be established to calculate the degree of hollowness. There are several basic data we should know, including the cell wall of windmill palm fibrils, which is noted as $d$, the large diameter noted as a, and short fibril diameter noted as $b$. Then calculate the degree of hollowness as shown in the equation (1):

hollowness $=\frac{S_{\text {lumen }}}{S_{\text {cross-section }}}=\frac{\pi(a-2 d)(b-2 d)}{\pi a b}$

The calculated hollowness of palm fibril is $47.21 \%$, the difference between the hollowness $(47.04 \%)$, which is measured by paper-cut method was $0.36 \%$. The hollowness of fibres, which had a similar elliptical cavity, can be calculated by measuring the large and short diameters and wall thickness. Thus, the test efficiency can be improved and increase the number of samples in order to ensure accuracy and reliability of the test results.

Table 1 - Morphological parameters of the cross-section of palm fibril

Tablica 1 - Morfološki parametri poprečnog presjeka niti palme

\begin{tabular}{|c|c|c|c|c|c|c|c|c|c|c|c|c|c|c|}
\hline \multicolumn{3}{|c|}{$\begin{array}{l}\text { Short diameter / } \mu \mathrm{m} \\
\text { Kraći promjer / } \mu \mathrm{m}\end{array}$} & \multicolumn{3}{|c|}{$\begin{array}{l}\text { Long diameter } / \mu \mathrm{m} \\
\text { Dulji promjer } / \mu \mathrm{m}\end{array}$} & \multicolumn{3}{|c|}{$\begin{array}{l}\text { Thickness of palm } \\
\text { fibril cell wall } / \mu \mathrm{m} \\
\text { Debljina stanične } \\
\text { stijenke niti palme } / \mu \mathrm{m}\end{array}$} & \multicolumn{3}{|c|}{$\begin{array}{l}\text { Thickness of palm } \\
\text { fibril cell wall } \\
\text { (long diameter) } / \mu \mathrm{m} \\
\text { Debljina stanične } \\
\text { stijenke niti palme } \\
\text { (dulji promjer) } / \mu \mathrm{m}\end{array}$} & \multicolumn{3}{|c|}{$\begin{array}{l}\text { Thickness of palm } \\
\text { fibril cell wall } \\
\text { (short diameter)/ } \mu \mathrm{m} \\
\text { Debljina stanične } \\
\text { stijenke niti palme } \\
\text { (kraći promjer) } / \mu \mathrm{m}\end{array}$} \\
\hline $\min$ & $\max$ & $\begin{array}{l}\text { average } \\
\text { prosjek }\end{array}$ & $\min$ & $\max$ & $\begin{array}{l}\text { average } \\
\text { prosjek }\end{array}$ & $\min$ & $\max$ & $\begin{array}{l}\text { average } \\
\text { prosjek }\end{array}$ & $\min$ & $\max$ & $\begin{array}{l}\text { average } \\
\text { prosjek }\end{array}$ & $\min$ & $\max$ & $\begin{array}{l}\text { average } \\
\text { prosjek }\end{array}$ \\
\hline 17.34 & 6.57 & 10.35 & 13.32 & 4.12 & 7.33 & 3.57 & 0.66 & 1.33 & 0.96 & 0.12 & 0.37 & 1.41 & 0.21 & 0.63 \\
\hline
\end{tabular}




\section{Conclusions}

The cylindrical windmill palm fibre has a sharp end. A large number of silica exists around the rough surface. Cross-section of windmill palm fibre is irregularly round. Near the centre, there is a large cavity and the rest are single palm fibrils. Spindly palm fibril without convolution has an ellipse cross-section and a larger lumen.

Palm fibril in different parts becomes shorter for the diameter decreasing of fibre, while the thickness of windmill palm fibril becomes thinner. The difference is so small, thus, where we obtain the windmill palm fibre has little effect on the characteristics of fibril. The average length of fibril is $643.60 \mu \mathrm{m}$, the average long diameter is $10.35 \mu \mathrm{m}$, while the short diameter is $7.33 \mu \mathrm{m}$. The thickness of palm fibril cell wall is about $1.33 \mu \mathrm{m}$.

Considering the cross-section as elliptic, an elliptic model can be established in order to calculate the degree of hollowness. The degree of hollowness by elliptic model and paper-cut method correspond well, and the difference between them is only $0.36 \%$. Windmill palm fibril is a natural hollow fibre with a hollow degree of $47.21 \%$, and may be suitable for the preparation of high-quality sound insulation and heat preservation materials.

\section{ACKNOWLEDGEMENT}

This work is funded by Priority Academic Program Development of Jiangsu Higher Education Institutions, China (No. 37 [2014]); Nantong Technological Innovation Project, China (No. XA2012006); and Jiangsu Province Special Project, China (No. BY2014083).

\section{List of abbreviations and symbols \\ Popis kratica i simbola}

a - large fibril diameter

- dulji promjer niti

b - short fibril diameter

- kraći promjer niti

d $\quad$ - cell wall of windmill palm fibrils

- stanične stijenke niti palme vjetrenjače

$x \quad-$ length

- duljina

y - fraction

- udjel

SEM - scanning electron microscopy

- skenirajuća elektronska mikroskopija

\section{References \\ Literatura}

1. J. L. Guimares, E. Frollini, C. G. da Silva, F. Wypych, K. G. Satyanarayana, Characterization of banana, sugarcane bagasse and sponge gourd fibers of Brazil, Ind. Crop. Prod. 30 (3) (2009) 407-415.
2. J. M. O. Scurlock, D. C. Dayton, B. Hames, Bamboo: An overlooked biomass resource, Biomass Bioenergy. 19 (4) (2000) 229-244, doi: http://dx.doi.org/10.1016/S09619534(00)00038-6.

3. S. Sreenivasan, B. T. H. T. Baharudin, M. K. A. Ariffin, K. Abdan, Recent developments of kenaf fibre reinforced thermoset composites: Review, Mater. Res. Innov. 17 (S2) (2013) 2-11, doi: http://dx.doi.org/10.1179/143289171 3Z.000000000312.

4. Y. K. Wu, Y. B. Li, B. Niu, Investigation of mechanical properties of randomly distributed sisal fibre reinforced soil, Mater. Res. Innov. 18 (S2) (2014) 953-959, doi: http://dx.doi.org/1 0.1179/1432891714Z.000000000511.

5. I. A.W. Tan, B. H. Hameed, A. L. Ahmad, Equilibrium and kinetic studies on basic dye adsorption by oil palm fibre activated carbon. Chem. Eng. J. 127 (1) (2007) 111-119, doi: http://dx.doi.org/10.1016/j.cej.2006.09.010.

6. A. Hassan, A. A. Salema, F. N. Ani, A. Abu Baker, A Review on Oil Palm Empty Fruit Bunch Fiber-Reinforced Polymer Composite Materials, Polym. Composite. 31 (S2) (2014) 2079-2101.

7. M. Shafiei, K. Karimi, M. J. Taherzadeh, Palm date fibers: Analysis and enzymatic hydrolysis, Int. J. Mol. Sci. 11 (11) (2010) 4285-4296, doi: http://dx.doi.org/10.3390/ijms11114285.

8. F. M. Al-Oqla, S. M. Sapuan, Natural fiber reinforced polymer composites in industrial applications: Feasibility of date palm fibers for sustainable automotive industry, J. Clean. Prod. 66 (2014) 347-354, doi: http://dx.doi.org/10.1016/j. jclepro.2013.10.050.

9. A. S. Harmaen, A. Khalina, A. R. Faizal, M. Jawaid, Effect of Triacetin on Tensile Properties of Oil Palm Empty Fruit Bunch Fiber-Reinforced Polylactic Acid Composites, Polym.-Plast. Technol. 52 (4) (2013) 400-406, doi: http://dx.doi.org/10.1 080/03602559.2012.754897.

10. M. Jawaid, O.Y. Alothman, M. T. Paridah, H. P. S. A. Khalil, Effect of Oil Palm and Jute Fiber Treatment on Mechanical Performance of Epoxy Hybrid Composites, Int. J. Polym. Anal. Ch. 19 (1) (2014) 62-69, doi: http://dx.doi.org/10.1080/10 23666X.2014.858429.

11. A. Shalwan, B. F. Yousif, Influence of date palm fiber and graphite filler on mechanical and wear characteristics of epoxy composites, Mater. Des. 59 (2014) 264-273, doi: http://dx.doi.org/10.1016/j.matdes.2014.02.066.

12. M. Rivai, A. Gupta, M. R. Islam, M. D. H. Beg, Characterization of Oil Palm Empty Fruit Bunch and Glass Fibre Reinforced Recycled Polypropylene Hybrid Composites, Fibers Polym.15 (7) (2014) 1523-1530, doi: http://dx.doi. org/10.1007/s12221-014-1523-y.

13. W. J. Zhang, Trees of China, Beijing: Chin. Forestry press, (2004).

14. M. Zhang, The industry of palm tree on Hong He country, Mod. Const. 11 (3) (2012) 48-49.

15. S. C. Zhai, Structural, chemical and physical properties of palm fiber, Nanjing: Nanjing Forest. Univ. (2010).

16. G. Z. Chen, Determination of hollowness of fiber in paper cutting method, Guangdong Prov. Chem. Fiber Res. Inst. 2 (1994) 35-37.

17. K. N. Law, W. R. W. Daud, A. Ghazali, Morphological and chemical nature of fiber strands of oil palm empty-fruitbunch (OPEFB), BioResources 3 (2) (2007) 351-362.

18. N. Li, H. Liu, S. Y. Fu, S. C. Chen, Cell-type-dependent enzymatic hydrolysis of palm residues: Chemical and surface characterization of ZHAO and parenchyma cells, Biotechnology Lett. 35 (2) (2013) 213-218, doi: http://dx.doi. org/10.1007/s10529-012-1079-0. 
19. M. Niu, H. Gao, G. J. Zhao, Fiber morphology and chemical composition of tension wood in Populus $\times$ Euramericana $\mathrm{CV}$ Neva, J. Beijing Forest. Univ. 2 (32) (2010) 141-144.

20. M. Yao, Textile Material, Beijing: Chin. Textile Press. (2009).

21. Y. X. Zhang, Textile Material, Beijing: Chin. Textile Press. (2010).

22. Q. A. Cao, Z. Z. Li, Study on morphology characteristics of sweet bamboo fiber from Vietnam, Chem. Ind. Forest. Prod. 30 (1) (2010) 40-43.
23. Q. Wu, J. C. Chen, G. H. Yang, S. F. Wang, Z. Q. Pang, Fiber morphology, chemical composition and APMP pulp properties of fast growing B lack poplar crotches, Chem. Ind. Forest. Prod. 30 (3) (2010) 36-40.

24. J. X. Jiang, Z. K. Yang, L. W. Zhu, L. M. Shi, L. J. Yan, Structure and property of bamboo fiber, J. Beijing Forest. Univ. 1 (30) (2008) 128-132.

25. H. B. Liu, J. H. Zhang, Y. G. Bai, S. J. Zhang, P. Ding, Pear Leaf Area Measurement Method, Xinjiang Agricult. Sci. 30 (50) (2013) 453-459.

\title{
SAŽETAK
}

Morfološko istraživanje materijala palme vjetrenjače (Trachycarpus fortunei)

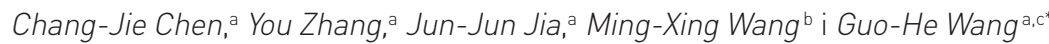

Vlakno palme vjetrenjače (Trachycarpus fortunei) prikupljeno je iz različitih dijelova plašta palmina debla, a zatim je tretirano otopinom natrijeva hidroksida i vodikova peroksida za dobivanje obrađene niti palme. Proučavani su izgled sirovog vlakna palme vjetrenjače i obrađene niti palme te njihove morfološke karakteristike, a provedena je i statistička analiza duljine niti, promjera i stupnja šupljikavosti. Rezultati su pokazali da cilindrično vlakno palme vjetrenjače ima oštar završetak. $\mathrm{SiO}_{2}$-tijela ravnomjerno su raspoređena preko vlakana, tvoreći hrapavu površinu. Vretenasto tretirana nit palme bez preklapanja ima elipsasti poprečni presjek i veću šupljinu. Mjesto prikupljanja vlakna palme ima mali utjecaj na karakteristike niti. Prosječna duljina tretirane palmine niti je $643,60 \mu \mathrm{m}$, a prosječan dulji promjer je 10,35 $\mu \mathrm{m}$. Udio šupljina određen eliptičnim modelom i papir-cut metodom približno odgovaraju i razlika među njima je samo $0,36 \%$. Nit palme vjetrenjače prirodno je šuplje vlakno sa šupljikavošću od oko $47.21 \%$.

Ključne riječi

Palma vjetrenjača, vlakno, nit, morfološka struktura

a College of Textile and Clothing Engineering,

Soochow University, 215006 Suzhou, Kina

b Violet Home Textile Company, 226311

Nantong, Kina

' Nantong textile institute of Soochow university,

226108 Nantong, Kina
Izvorni znanstveni rad Prispjelo 17. ožujka 2015. Prihvaćeno 23. svibnja 2015. 